\title{
Improvement of High Strength Automotive Steels Wettability Properties Using CO2 Laser Surface Treatment
}

\author{
F. TAJTI ${ }^{1}$, M. BERCZELI ${ }^{2}$, Z. WELTSCH ${ }^{3}$ \\ ${ }^{1}$ John Von Neumann University, GAMF Faculty of Engineering and Computer Science, Department of Materials \\ Technology, cbfferi@gmail.com \\ ${ }^{2}$ John Von Neumann University, GAMF Faculty of Engineering and Computer Science, Department of Materials \\ Technology, berczeli.miklos@gamf.uni-neumann.hu \\ ${ }^{3}$ John Von Neumann University, GAMF Faculty of Engineering and Computer Science, Department of Materials \\ Technology, weltsch.zoltan@gamf.uni-neumann.hu
}

Abstract. As a result of stricter environmental and safety standards, vehicle manufacturers have to reduce the weight of the vehicles, because 10\% weight loss cause 8-10\% reduction of fuel consumption. To reduce car's weight and increase safety, vehicle manufacturers use high-strength steels. Further weight reduction can be achieved by using corresponding bonding technology (soldering, sticking) and optimizing these technologies can increase the strength of the joints. According to literature research, the improvement of interface properties has a large effect on bonding technologies. In order to improve interface properties, we can use multiple surface treatments. In our research we investigate the effects of $\mathrm{CO} 2$ laser surface treatment on high strength steels, because CO2 lasers are often used in the vehicle industry. In order to detect the effect of surface treatment, we investigate the wettability of the treated and untreated steels. In our research we measure the surface tension of treated and untreated steels. Our main goal is to improve wettability properties thus the bonding technology.

In our research we used DP 600 high strength steel sheet with the thickness of $1 \mathrm{~mm}$. We cut the steel sheet to $25 \mathrm{~mm}$ wide and $55 \mathrm{~mm}$ long workpieces. Before the surface treatment, the workpieces had to be cleaned and degreased using methanol. We searched for parameters that do not cause any visible changes on the surfaces. Among the parameters of the treatment we were able to change the output power of the laser. We used contact angle measurement to examine the wettability.

\section{Introduction}

The increasing number of vehicles occurs various social and environmental problems therefore vehicle manufacturers have to comply with increasingly stringent environmental and safety standards. From 2020 vehicles CO2 emissions should not exceed $95 \mathrm{~g} / \mathrm{km}$. Nowadays, the automotive industry has a major role in reducing vehicle's weight to minimize harmful emissions. According to recent research, $57 \mathrm{~kg}$ weight reduction causes fuel consumption reduction of 0.09-0.21 liter per kilometer. To achieve this goal car manufacturers should use materials which have lighter weight but higher strength. This is achieved by using modern materials and joining hybrid materials, depending on what 
function they need to fill in the car body [1.2]. On (Figure 1.) you can see what kind of materials used in a modern car's body [3].

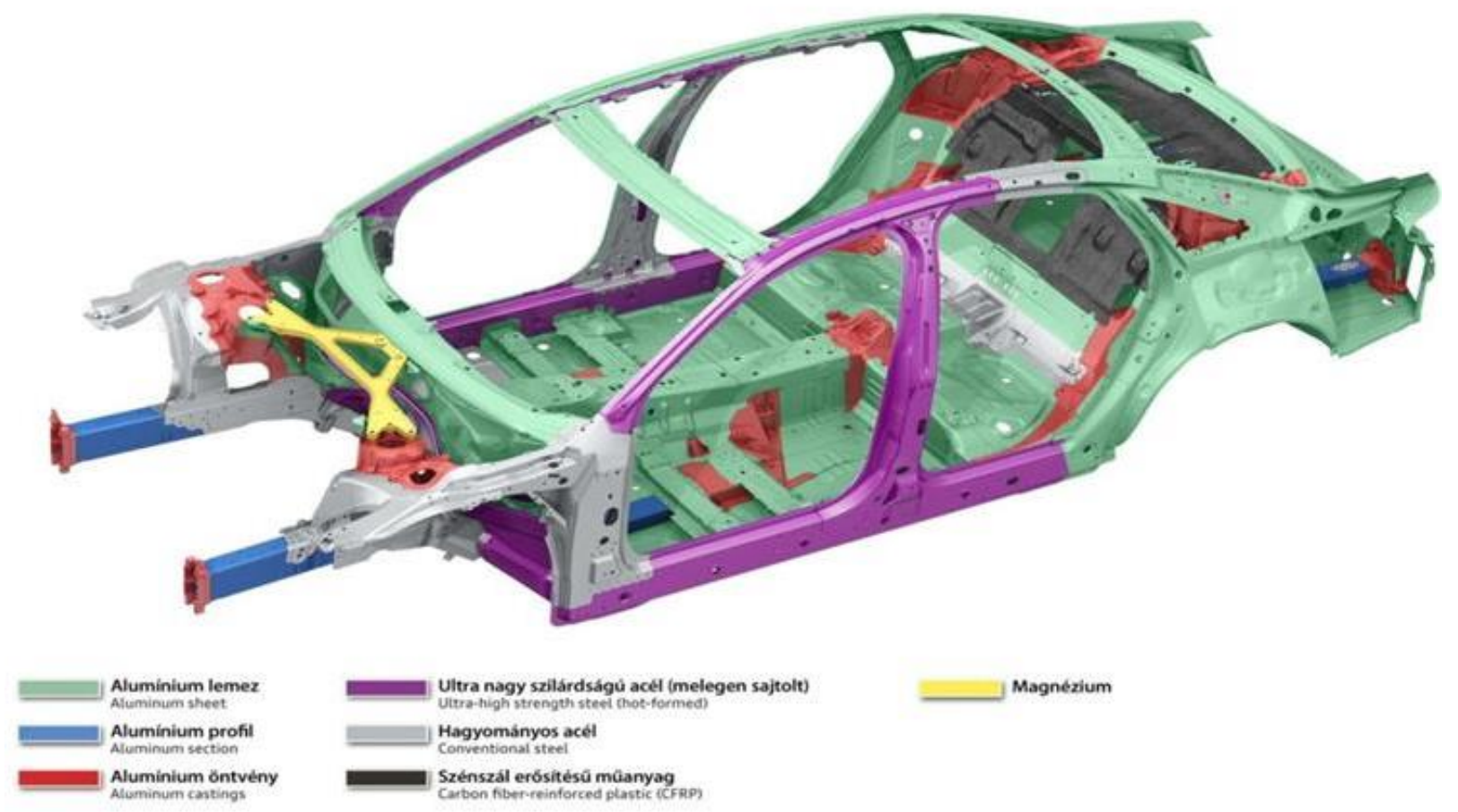

Figure 1. A modern car's body [3].

It can be seen that high-strength steels used in security-relevant areas, while aluminium alloys and conventional steels are used in energy-absorbing zones. The aim of our future research is to optimize the soft soldered bonding of high strength steel sheets by laser beam surface treatment, thus increasing the bond strength.

\section{High strength DP steels}

Dual Phase Steel consists of hard-martensite embedded in soft, well-formed ferrite. The amount of martensite in general is between $10-60 \%$, depending on the desired mechanical properties. The gray parts shown in (Figure 2) illustrate ferrite grains that provide good formability, while the black parts indicate the martensitic granules responsible for high strength.

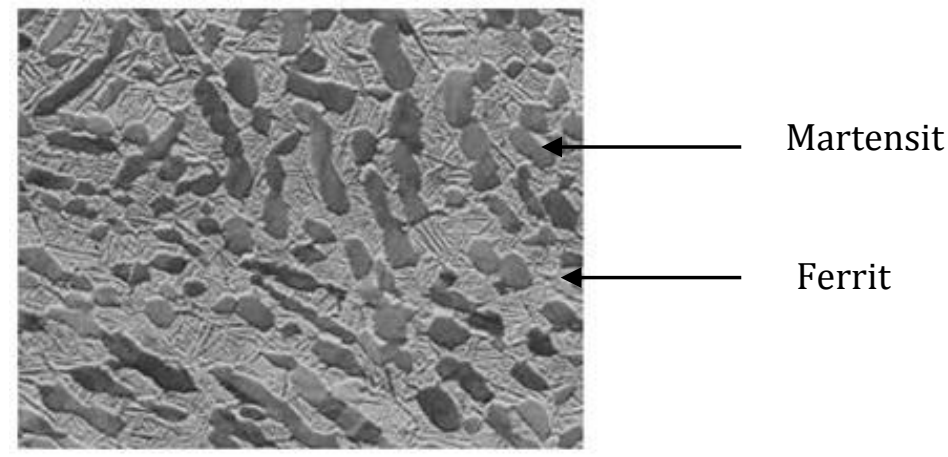

Figure 2. Microstructure of DP steels [4]. 
Dual phase steels can significantly reduce the weight of vehicles because high strength can be achieved with martensite thus the required strength can be achieved with thinner sheet thickness. They produce components that should withstand heavy loads in the event of a collision like door and roof elements, A and B pillars [4].

\section{Soldering}

By soldering, an insoluble bond can be made similarly to welding. Soldering is always made with a material which has lower melting point than the base material. The melted solder involves the base material, forming a surface alloy, then the diffusion process takes place on the interface, and it creates adhesion bond after cooling (3. Figure) [5].

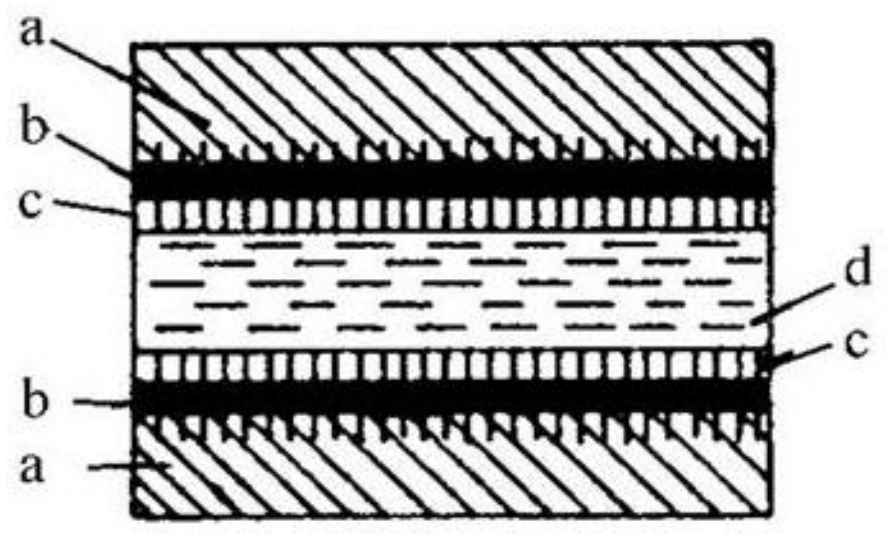

Figure 3. Solder bond zones a) base material; b) a diffusion layer in the base material; c) a diffusion layer in the solder; (d) the material of the solder [7]

Low melting alloys are generally used for soft soldering. The used tin alloys have relatively low melting point (up to $300^{\circ} \mathrm{C}$ ), which allows the use of electric-heated soldering-iron. Surfaces must be cleaned and degreased before the soldering process. Gas welding equipments are generally used for brazing. A relatively high strength bond can be made by using a higher melting point solder. The solder is mostly copper or silver with a melting point between 700 and $1000^{\circ} \mathrm{C}$. The removal of the oxide layer on the surface at high temperatures should be carried out with fluxing agent and cleaning agents (eg. borax) which, in molten condition, remove the oxide layer [6]. Although, the base material does not melt, but the diffusion takes place, which contributes to the formation of a strong bond. The molten solder have to wet the surface of the substrate. The contact angle must be less than $90^{\circ}$. Lower contact angle refers better wetting thus the solder can flow, spread easier on the surface [8].

\section{Wetting and interfacial energy}

Wetting means the spread of a liquid on a solid surface. The spreading can be characterized by the contact angle along the contact of two faces. Wetting is determined by the interactions between the two phases [9]. Measuring the contact angle can be done using the sessile drop method. A droplet of a 
liquid was dropped onto the surface. The droplet is illuminated against the camera then we take a photo of the droplet (Figure 4.). This can be done with melted solder too.

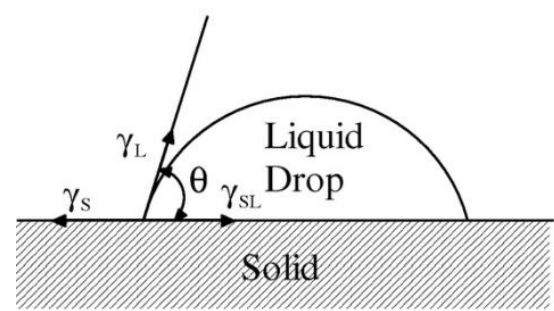

(a)

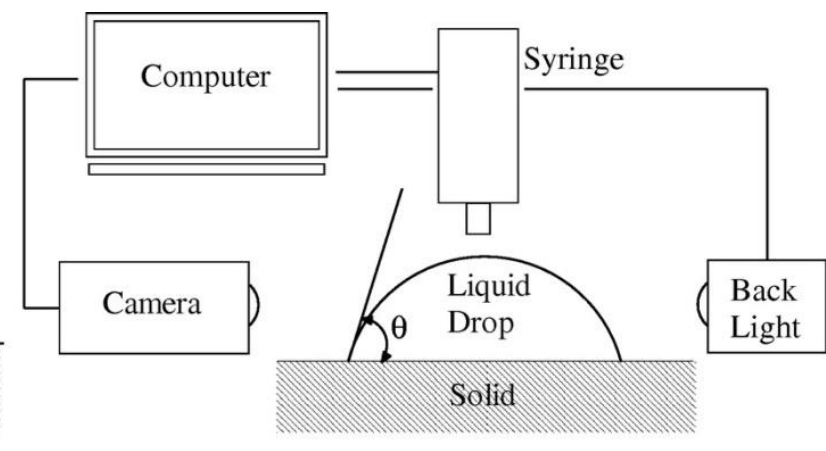

(b)

Figure 4. The outline of the sessile drop method [10].

Measurement based on sessile drop method is a relatively simple tool for determining hydrophobic or hydrophilic phenomena, solid surface energy, and liquid surface tension. From the shape of the droplet, we can conclude the extent of the wettability (Figure 5.).

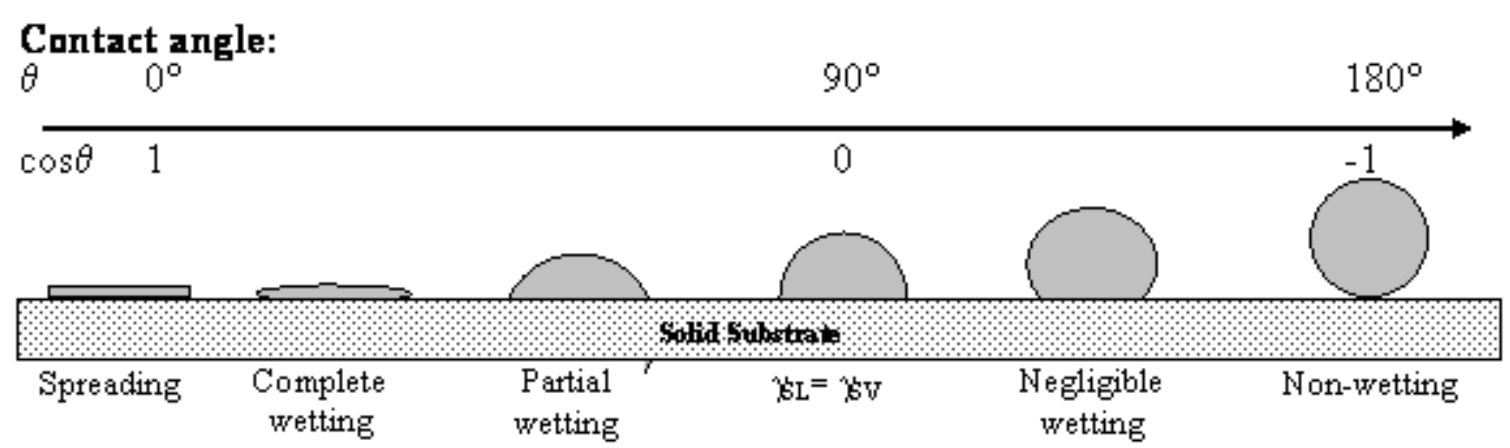

Figure 5. Droplet shapes on solid surface [10].

Wetting is depend on interfacial energy, roughness of the surface and cleanness. The interfacial energy can be calculated using the Fawkes method, this should be measured with two liquids contact angle, and then we will replace the measured contact angle values in the Fowkes equation to obtain the surface energy of the solid material.

$$
\begin{gathered}
\sigma_{S}{ }^{D}=\frac{\sigma_{L} \cdot(\cos \theta+1)^{2}}{4} \\
\left(\sigma_{L}{ }^{D}\right)^{1 / 2} \cdot\left(\sigma_{S}{ }^{D}\right)^{1 / 2}+\left({\sigma_{L}}^{P}\right)^{1 / 2} \cdot\left({\sigma_{S}}^{P}\right)^{1 / 2}=\frac{\sigma_{L} \cdot(\cos \theta+1)}{2}
\end{gathered}
$$

By increasing interfacial energy, wettability can be greatly increased. There are several ways to do this. According to literature research, I found that on metals, laser surface treatment has a great effect on surface energy [11]. 


\section{Laser surface treatment}

Over the last few years, the laser beam machining is widespread. Laser means Light Amplification by Stimulated Emission of Radiation. There are many types of lasers which differ in their physical size, performance, laser beam wavelength, and production cost. The great advantage of lasers is that almost all material processing methods can be achieved with them. The most important uses of lasers are cutting, welding and surface treatment, which require high energy density.

Over the last decades, the surface treatment technology is becoming increasingly important. The essence of surface treatment is to create the required properties for a part only where it is needed, thus significantly reduce the cost of machining. The quality of surface treatment is greatly influenced by the technological parameters, such as laser power, wavelength, beam shape, beam diameter and the scanning speed. With laser beam surface treatment, we can increase surface hardness which improves abrasion resistance. Laser surface treatment allows us to change the surface oxide layer and create a microstructure on the surface that affects the wettability [12].

L. Hao and partners was performed laser surface treatment on corrosion-resistant steel and it was found that the $\mathrm{O}_{2}$ concentration in the steel's interfacial layer was nearly doubled and the surface energy increased by $10 \%$ [13].

\section{Summary}

Nowadays, the industry is increasingly using lasers for machining. With laser surface treatment, we can economically change the surface properties and surface energy of metals. By increasing the surface energy, we can increase the wettability of adhesive binders, which can improve the strength of the joints. Soldering is also becoming more and more important in the automotive industry, so it is also a great opportunity for this development.

The aim of our future research is to perform surface treatment on high-strength steel sheets with $\mathrm{CO}_{2}$ laser. We will use sessile drop method to examine the effect of the surface treatment.

\section{Acknowledgments}

This research was supported by EFOP-3.6.1-16-2016-000014. The Project is supported by the Hungarian Government and co-financed by the European Social Fund.

\section{References}

[1] X. Cui - S. Wang - S. J. Hu (2008) A method for optimal design of automotive body assembly using multi-material construction. Materials and Design. pp. 381-387.

[2] CO2 kibocsátás 2020-tól [Online].

Available: https://hvg.hu/cegauto/A_legdurvabb_fogyokura_100_kilokat_is_ledob_I82L2X. [Accessed: 19-0kt-2018]. 
[3] Audi A8 car body 2017. [Online].

Avaliable:

http://totalcar.hu/galeria/totalcar/technika/2017/07/18/sajtogaleria_audi_a8_technologia. [Accessed: 19-Oct-2018]

[4] Dual Phase (DP) Steels. [Online]. Available: http://www.worldautosteel.org/steel-basics/steeltypes/dual-phasedp-steels/. [Accessed: 24-0kt-2018].

[5] L. Szabó (2000) Forgácsolás, hegesztés. Miskolc: Miskolci Egyetem. (2.4. fejezet). Available: http://www.uni-miskolc.hu/ wwwfemsz/forgacs.htm. [Accessed: 25-Okt-2018].

[6] Forrasztás [Online]. Available: http://tudasbazis.sulinet.hu/hu/szakkepzes/faipar/gepeszetiismeretek/forrasztas/kemeny-es-lagyforrasztas. [Accessed: 25-Okt-2018].

[7] J. Szántó (2013) Javítástechnológia (Károsodás-elmélet). (10.3. fejezet). Available: http://www.tankonyvtar.hu/hu/tartalom/tamop412A/2010-

0013_javitastechnologia_karosodas_elmelet/10_3_a_feluleti_feszultseg_hatasa.html. [Accessed: 25-Okt-2018]

[8] Gy. Bagyinszki - B. Borossay (2012) Anyagtechnológiák. Budapest: Budapesti Műszaki és Gazdaságtudományi Egyetem Gépészmérnöki Kar. p.1051.

[9] S. Balla - K. Bán - A. Bárdos - A. Lovas - A. Szabó - Z. Weltsch (2012) Jármüanyagok, Typotex Kiadó.

[10] D. O. Njobuenwu - E. O. Oboho - R. H. Gumus (2007) Determination of Contact Angle from Contact Area of Liquid Droplet Spreading on Solid Substrate. Leonardo Electronic Journal of Practices and Technologies. 10 pp. 29-38

[11] H. Chen - J. Peng - L. Fu - X. Wang - Y. Xie (2016) Solder wetting behavior enhancement via lasertextured surface microcosmic topography. Applied Surface Science. 368. pp. 208-215.

[12] E. Bitay (2007) Lézeres felületkezelés és modellezés. Kolozsvár: Erdélyi Múzeum-egyesület.

[13] L. Hao - J. Lawrence - L. Li (2007) The wettability modification of bio-grade stainless steel in contact with simulated physiological liquids by the means of laser irradiation. Applied Surface Science 247. 